CZASOPISMO INŻYNIERII LĄDOWEJ, ŚRODOWISKA I ARCHITEKTURY JOURNAL OF CIVIL ENGINEERING, ENVIRONMENT AND ARCHITECTURE

JCEEA, t. XXXIII, z. 63 (2/I/16), kwiecień-czerwiec 2016, s. 143-156

\author{
Edyta LASKAWIEC ${ }^{1}$ \\ Joanna WYCZARSKA-KOKOT ${ }^{2}$ \\ Mariusz DUDZIAK ${ }^{3}$
}

\title{
ANALIZA JAKOŚCI WODY BASENOWEJ W OBIEGACH O RÓŻNYCH ROZWIĄZANIACH UKŁADÓW FILTRACYJNYCH
}

\begin{abstract}
W pracy przedstawiono wyniki analiz fizykochemicznych oraz ocenę toksykologiczną wody z sześciu obiegów basenowych. Podstawową różnicą w zastosowanych technologiach wody obiegowej jest sposób jej filtracji. Do oceny jakościowej wybrano filtry ciśnieniowe o wypełnieniu piaskowo-antracytowy oraz z Aktywnego Szkła Filtracyjnego $\mathrm{AFM}^{\circledR}$, a także filtr podciśnieniowy z ziemią okrzemkową. Ponadto obiekty badań charakteryzowały się zróżnicowanym przeznaczeniem niecek basenowych. Ocenę toksykologiczną przeprowadzono w oparciu o test inhibicji bioluminescencji bakterii - Microtox ${ }^{\circledR}$ oraz biotest przeżywalności skorupiaków Daphnia magna. Analiza fizykochemiczna próbek wody basenowej wskazuje na duże zróżnicowanie jej jakości. W większości punktów poboru próbek wody stwierdzono stężenia chloru wolnego i związanego przekraczające wartości dopuszczalne, określone w DIN 19643 oraz rozporządzeniu Ministra Zdrowia. Wyniki przeprowadzonych biotestów wskazują na wysoką toksyczność wody basenowej w stosunku do organizmów testowych. Wrażliwość użytych organizmów wskaźnikowych na związki występujące w badanych próbkach była zbliżona. Wsparcie analizy fizykochemicznej przy pomocy narzędzi toksykologicznych umożliwia pełniejszy opis jakości wody basenowej. Przedstawione wyniki badań pokazują, że zachowanie odpowiedniej jakości wody basenowej, zgodnej z rygorystycznymi wymaganiami w tym zakresie stanowi duże wyzwanie dla wielu zarządców obiektów basenowych. Szczególnie wyraźnym problemem jest przekraczanie norm chloramin.
\end{abstract}

Słowa kluczowe: wskaźniki fizykochemiczne, chloraminy, ocena toksykologiczna, klasyfikacja toksykologiczna

\footnotetext{
${ }^{1}$ Autor do korespondencji / corresponding author: Edyta Łaskawiec, Politechnika Śląska, Instytut Inżynierii Wody i Ścieków, ul. Stanisława Konarskiego 18, 44-100 Gliwice tel. 322371698; edyta.laskawiec@polsl.pl

2 Joanna Wyczarska-Kokot, Politechnika Śląska, Instytut Inżynierii Wody i Ścieków, ul. Stanisława Konarskiego 18, 44-100 Gliwice, tel. 322371698; joanna.wyczarska-kokot@ polsl.pl

3 Mariusz Dudziak, Politechnika Śląska, Instytut Inżynierii Wody i Ścieków, ul. Stanisława Konarskiego 18, 44-100 Gliwice, tel. 322371698; mariusz.dudziak@ polsl.pl
} 


\section{Wprowadzenie}

Stopień zanieczyszczenia wody basenowej zależy przede wszystkim od obciążenia basenu osobami kąpiącymi się. Ponieważ głównym procesem w systemie uzdatniania wody basenowej jest filtracja, jej sprawność powinna zapewnić jakość wody zgodną z przyjętymi wytycznymi niezależnie od zastosowanej technologii oraz obciążenia niecki basenowej [1-3]. W trakcie filtracji zachodzi przede wszystkim oddzielanie części stałych na powierzchni i wewnątrz złoża filtracyjnego, któremu mogą towarzyszyć dodatkowe chemiczne i biologiczne procesy. Pozwala to na usunięcie mętności, zawiesin oraz mikroorganizmów $[4,5]$. Filtry mogą być projektowane zarówno jako urządzenia otwarte, jak i zamknięte, działając w systemie podciśnieniowym lub ciśnieniowym.

Dobór odpowiedniej technologii wody basenowej zależy od wielu czynników, a każdy obiekt stanowi indywidualny przypadek. Gwarancją uzyskania wymaganej jakości wody basenowej zgodnej z bardzo rygorystycznymi wymaganiami sanitarno-higienicznymi w tym zakresie oprócz nowoczesnej technologii są kontrola jej jakości i prawidłowa eksploatacji basenu.

Opublikowane w grudniu 2015 roku Rozporządzenie Ministra Zdrowia w sprawie wymagań jakim powinna odpowiadać woda na pływalniach (Dz. U. 2015. poz. 2016) w sposób szczegółowy reguluje zakres podstawowych parametrów jakości wody basenowej, częstość poboru próbek wody oraz metody ich badania. Mając na uwadze te wymagania wielu właścicieli obiektów basenowych zostało zmuszonych do weryfikacji skuteczności systemów uzdatniania wody.

Celem niniejszej pracy jest porównanie sprawności działania różnych rozwiązań filtrów basenowych, w oparciu o analizę fizykochemiczną podstawowych parametrów dla próbek pobranych w wybranych etapach uzdatniania wody basenowej. Ocenę jakości fizykochemicznej próbek wody prowadzono w oparciu o aktualnie stosowane w tym zakresie standardy [1-3]. Ponadto dla części z badanych obiegów wykonano ocenę toksykologiczną z wykorzystaniem biotestu bakteryjnego Microtox ${ }^{\circledR}$ oraz testu przeżywalności skorupiaków Daphnia magna, która miała na celu określenie wpływu chloru oraz jego związków na organizmy testowe [6].

\section{Metodyka badań}

\subsection{Charakterystyka badanych obiektów basenowych}

Przedmiotem badań były próbki wody pobrane $\mathrm{z}$ niecek, ze zbiorników przelewowych, z kurków probierczych przed i po filtrach lub po dezynfekcji, w trakcie codziennej eksploatacji basenów. Wszystkie badane obiekty charakteryzują się wysokim obciążeniem lustra wody osobami kąpiącymi się. W przykładowo przypadku niecki do nauki pływania jest to od 9 do 22 osób na godzinę. $\mathrm{W}$ tabeli 1 przedstawiono podstawowe informacje o badanych basenach. 
Tabela 1. Charakterystyka badanych obiegów basenowych i stosowanej technologii filtracji

Table 1 . The characteristics of swimming pool waters circulations and filtration technology

\begin{tabular}{|c|c|c|c|c|c|}
\hline $\begin{array}{c}\text { Obiekt } \\
\text { basenowy }\end{array}$ & $\begin{array}{l}\text { Numer } \\
\text { obiegu }\end{array}$ & Rodzaj basenu & $\begin{array}{l}\text { Powierzch- } \\
\text { nia lustra } \\
\text { wody }\left[\mathrm{m}^{2}\right]\end{array}$ & Technologia filtracji & $\begin{array}{c}\text { Wydaj- } \\
\text { ność filtra } \\
{\left[\mathbf{m}^{3} / \mathbf{h}\right]}\end{array}$ \\
\hline $\begin{array}{l}\text { Szkolna } \\
\text { pływalnia } \\
\text { kryta }\end{array}$ & 1 & $\begin{array}{l}\text { basen do nauki } \\
\text { pływalnia }\end{array}$ & 90 & $\begin{array}{l}\text { filtr ciśnieniowy pia- } \\
\text { skowo-antracytowy }\end{array}$ & 23 \\
\hline \multirow{2}{*}{$\begin{array}{l}\text { Basen } \\
\text { kryty } 1\end{array}$} & 2 & $\begin{array}{l}\text { wanny z hydro- } \\
\text { masażem }\end{array}$ & 4,15 & $\begin{array}{l}\text { filtr ciśnieniowy pia- } \\
\text { skowo-antracytowy }\end{array}$ & 30 \\
\hline & 3 & tunel wodny & 4,15 & $\begin{array}{l}\text { filtr ciśnieniowy pia- } \\
\text { skowo-antracytowy }\end{array}$ & 30 \\
\hline \multirow{3}{*}{$\begin{array}{l}\text { Basen } \\
\text { kryty } 2\end{array}$} & 4 & $\begin{array}{l}\text { basen rekreacyj- } \\
\text { ny }+2 \text { wanny z } \\
\text { hydromasażem }\end{array}$ & 156,2 & $\begin{array}{l}\text { filtr podciśnieniowy z } \\
\text { ziemią okrzemkową }\end{array}$ & 116 \\
\hline & 5 & basen pływacki & 400 & $\begin{array}{l}\text { filtr podciśnieniowy z } \\
\text { ziemią okrzemkową }\end{array}$ & 178 \\
\hline & 6 & $\begin{array}{l}\text { brodzik dla dzie- } \\
\text { ci }\end{array}$ & 29,9 & $\begin{array}{c}\text { filtr ciśnieniowy ze } \\
\text { złożem szklanym } \\
\text { AFM }^{\circledR}\end{array}$ & 22 \\
\hline
\end{tabular}

We wszystkich badanych obiegach wody basenowej filtracja jest podstawowym procesem uzdatniania. Woda do niecek doprowadzana jest systemem dennych lub bocznych dysz z regulowanym przepływem. Natomiast odprowadzanie odbywa się poprzez rynny przelewowe do zbiorników przelewowych, w których straty wody powstałe w wyniku rozchlapywani, parowania, czy płukania filtrów uzupełniane są świeżą wodą wodociągową. Woda następnie pompowana jest do zespołu filtrów. W przypadku filtracji ciśnieniowej do rurociągu przed filtrami dozowany jest koagulant (najczęściej hydroksychlorek glinu). Oczyszczona woda jest podgrzewana w wymiennikach ciepła, poddawana dezynfekcji i korekcie pH. Rozpatrywane obiekty basenowe są wyposażone w automatyczne układy kontroli jakości wody (temperatura, redox, $\mathrm{pH}$, chlor wolny).

\subsection{Procedura analityczna oraz ocena toksykologiczna}

Analizy fizykochemiczne obejmowały pomiar odczynu (pH), przewodności właściwej, absorbancji w nadfiolecie przy długości fali $254 \mathrm{~nm}$, stężenia chloru wolnego i całkowitego, oraz azotu amonowego i azotanowego w próbkach wody basenowej. Pomiar stężenia chloru, metodą kolorymetryczną, wykonano przenośnym urządzeniem Pocket Colorimeter ${ }^{\mathrm{TM}}$ II firmy Hach ${ }^{\circledR}$. Stężenia azotu azotanowego oraz amonowego określono przy użyciu testera photolyser 400 (Dinotec). Pomiar przewodności właściwej oraz $\mathrm{pH}$ próbek wody wykonano miernikiem wieloparametrowym inoLab ${ }^{\circledR} 740$ (WTW, Pomiarowy i Analityczny 
Sprzęt Techniczny). Absorbancję mierzono z użyciem UV VIS Cecil 1000 firmy Analytik Jena AG, przy długości drogi optycznej kuwety d = 1cm. Wartość absorbancji przy długości fali $254 \mathrm{~nm}$ wyznaczono w oparciu o metodę pomiaru absorbancji $\mathrm{w}$ nadfiolecie $\mathrm{UV}_{254}$, zgodnie ze standardami przyjętymi przez US EPA [7], a ostateczny wynik analizy zestawiono jako $\mathrm{UV}_{254} \mathrm{~W} \mathrm{~m}^{-1}$.

Wodę w wybranych obiegach basenowych poddano ocenie toksykologicznej z wykorzystaniem testu bakteryjnego Microtox ${ }^{\circledR}$, który pozwala na określenie wielkości efektu toksycznego na podstawie inhibicji bioluminescencji bakterii Aliivibrio fischeri. Biotest został przeprowadzony w oparciu o procedurę Screening Test systemu MicrotoxOmni w analizatorze Microtox Model 500 firmy Tigret Sp. z. o. o. pełniącym rolę zarówno inkubatora, jak i fotometru. Procent inhibicji względem próby kontrolnej zawierającej bakterie nie poddane działaniu potencjalnego toksykanta, zmierzono po 5 i 15 minutowym czasie ekspozycji.

Test toksyczności w wykorzystaniem skorupiaków Daphnia magna przeprowadzono według metodyki własnej w oparciu o zalecenia OECD [8]. Organizmy pochodziły $\mathrm{z}$ hodowli testowej. Do przeprowadzenia testu wykorzystano po $10 \mathrm{~cm}^{3}$ próbek wód basenowych, które umieszczono w dołkach testowych, a następnie wprowadzono do nich nowonarodzone skorupiaki. Płytki inkubowano w temperaturze $20^{\circ} \mathrm{C}$ w ciemności. Określenia liczby unieruchomionych i uśmierconych organizmów dokonano po 24 oraz 48 godzinach. Dla każdej z próbek wód basenowych oraz próby kontrolnej stanowiącej standardową pożywkę do hodowli Daphnia magna, obliczono procentowy efekt toksyczności.

Przeprowadzona ocena toksykologiczna miała miejsce w odpowiednim odstępie czasu (3 doby) zapewniającym zminimalizowanie wpływu chloru wolnego na procesy metaboliczne i funkcje życiowe organizmów wykorzystywanych w biotestach.

Klasyfikacji toksyczności próbek wody basenowej dokonano w oparciu o system opisany przez Persoone'a i in., wykorzystujący wielkość obserwowanego efektu toksycznego u organizmu wskaźnikowego (Tabela 2) [9]. Wyniki oceny toksykologicznej przedstawiono $\mathrm{w}$ formie wykresów słupkowych (Rys. 1\%6).

Tabela 2. System klasyfikacji toksyczności, na podstawie [9]

Table 2. The classification system for toxicity, based on [9]

\begin{tabular}{|c|c|}
\hline Efekt [\%] & Klasa toksyczności \\
\hline$<25$ & nietoksyczna \\
\hline $25 \div 50$ & niska toksyczność \\
\hline $50,1 \div 75$ & toksyczna \\
\hline $75,1 \div 100$ & wysoka toksyczność \\
\hline
\end{tabular}




\section{Wyniki badań}

\subsection{Analiza fizykochemiczna}

W tabelach $3 \div 8$ przedstawiono wyniki analizy fizykochemicznej dla poszczególnych obiegów. W większości próbek wody pobranych z obiegów z filtrami piaskowo-antracytowymi (obiegi nr 1-3) wartości $\mathrm{pH}$ oraz przewodnictwa właściwego odpowiadały zalecanym wartościom ustalonym $\mathrm{w}$ rozporządzeniach [1-3]. Podwyższone wartości przewodności odnotowano dla próbek pobranych z obiegu wanny z hydromasażem (Tabela 4). Przyczyną może być bliska odległość od drugiej wanny z hydromasażem, która jest wypełniona solanką. Dochodzić może do przenoszenia resztek soli na ciele oraz ubraniach osób kąpiących się do wanny $\mathrm{z}$ wodą słodką. Wartość absorbancji w nadfiolecie $\mathrm{w}$ poszczególnych obiegach wykazywała zróżnicowane wartości. W przypadku obiegów basenu do nauki pływania (Tabela 3) oraz wanny z hydromasażem (Tabela 4) nie odnotowano podwyższonych wartości, co świadczy o niewielkim udziale związków zawierających pierścienie aromatyczne, które mogą się przyczynić do powstawania niebezpiecznych dla zdrowia ubocznych produktów dezynfekcji. W przypadku obiegu tunelu wodnego (Tabela 5) próbka pobrana jako prefiltrat charakteryzowała się wysoką wartością absorbancji, wynoszącą $109,90 \mathrm{~m}^{-1}$, co mogło być spowodowane dużą ilością zawiesin obecnych w próbce. Ponadto wartość absorbancji na poziomie $12 \mathrm{~m}^{-1}$ w filtracie wskazuje na ryzyko zatężania ubocznych produktów dezynfekcji w tym obiegu. Jest to wartość podwyższona w stosunku do danych przedstawionych w literaturze dla wody uzdatnionej [10]. Próbka pobrana, jako odpływ do kanalizacji stanowiła wodę technologiczną po procesie płukania, która była odprowadzana bezpośrednio do sieci kanalizacyjnej.

Tabela 3. Parametry fizykochemiczne wody w obiegu basenu do nauki pływania

Table 3. Physicochemical parameters of water in circulation swimming pool to learn swimming

\begin{tabular}{|c|c|c|c|c|c|}
\hline \multirow{2}{*}{ Parametr } & \multirow{2}{*}{ Jednostka } & $\begin{array}{c}\text { Niecka, } \\
\text { głębokość } \\
\mathbf{0 , 0 ~ m ~}\end{array}$ & $\begin{array}{c}\text { Niecka, } \\
\text { głębokość } \\
\mathbf{0 , 3} \mathbf{~ m}\end{array}$ & $\begin{array}{c}\text { Po chloro- } \\
\text { waniu }\end{array}$ & $\begin{array}{c}\text { Odpływ do } \\
\text { kanalizacji }\end{array}$ \\
\hline Odczyn $(\mathrm{pH})$ & {$[-]$} & 7,80 & 7,50 & 7,47 & 7,40 \\
\hline $\begin{array}{c}\text { Przewodnictwo } \\
\text { właściwe }\end{array}$ & {$[\mu \mathrm{S} / \mathrm{cm}]$} & 1509 & 1142 & 1470 & 1442 \\
\hline $\begin{array}{c}\text { Absorbancja } \\
\text { UV }\end{array}$ & {$\left[\mathrm{m}_{254}^{-1}\right]$} & 2,00 & 2,30 & 2,93 & 2,90 \\
\hline Chlor całkowity & {$\left[\mathrm{mgCl}_{2} / \mathrm{dm}^{3}\right]$} & 1,14 & 0,99 & 0,91 & 0,51 \\
\hline Chlor wolny & {$\left[\mathrm{mgCl}_{2} / \mathrm{dm}^{3}\right]$} & 0,58 & 0,27 & 0,48 & 0,03 \\
\hline Chlor związany & {$\left[\mathrm{mgCl}_{2} / \mathrm{dm}^{3}\right]$} & 0,56 & 0,72 & 0,43 & 0,48 \\
\hline Azot amonowy & $\begin{array}{c}{\left[\mathrm{mgN}^{3}\right.} \\
\left.\mathrm{NH}_{4} / \mathrm{dm}^{3}\right]\end{array}$ & 0,35 & 0,44 & 0,36 & 1,46 \\
\hline Azot azotanowy & $\begin{array}{c}{\left[\mathrm{mgN}^{-}\right.} \\
\left.\mathrm{NO}_{3} / \mathrm{dm}^{3}\right]\end{array}$ & 17,00 & 21,00 & 13,00 & 24,00 \\
\hline
\end{tabular}


Zgodnie z Rozporządzeniem Ministra Zdrowia w sprawie jakości wody na pływalniach stężenie chloru wolnego w nieckach basenowych nie powinno przekraczać $0,6 \mathrm{mgCl}_{2} / \mathrm{dm}^{3}$, natomiast $\mathrm{w}$ wannach $\mathrm{z}$ hydromasażem $0,7-1,0 \mathrm{mgCl}_{2} / \mathrm{dm}^{3}[3]$. Próbki wody pobrane $\mathrm{z}$ wanny $\mathrm{z}$ hydromasażem oraz tunelu wodnego wykazywały odpowiednio wartości 0,85 oraz $0,97 \mathrm{mgCl} / \mathrm{dm}^{3}$.

Tabela 4. Parametry fizykochemiczne wody w obiegu wanny z hydromasażem

Table 4. Physicochemical parameters of water in circulation for hot tubs

\begin{tabular}{|c|c|c|c|c|c|}
\hline \multirow{2}{*}{ Parametr } & \multirow{2}{*}{ Jednostka } & \multicolumn{4}{|c|}{ Miejsce poboru próbki wody } \\
\cline { 3 - 6 } & $\begin{array}{c}\text { Wanna z hy- } \\
\text { dromasażem }\end{array}$ & $\begin{array}{c}\text { Zbiornik } \\
\text { przelewowy }\end{array}$ & Prefiltrat & Filtrat \\
\hline Odczyn $(\mathrm{pH})$ & {$[-]$} & 7,45 & 7,51 & 6,81 & 7,02 \\
\hline $\begin{array}{c}\text { Przewodnictwo } \\
\text { właściwe }\end{array}$ & {$[\mu \mathrm{S} / \mathrm{cm}]$} & 2549 & 2604 & 2565 & 2365 \\
\hline $\begin{array}{c}\text { Absorbancja } \\
\mathrm{UV}_{254}\end{array}$ & {$\left[\mathrm{~m}^{-1}\right]$} & 2,10 & 3,50 & 4,40 & 8,00 \\
\hline Chlor całkowity & {$\left[\mathrm{mgCl}_{2} / \mathrm{dm}^{3}\right]$} & 1,37 & 0,89 & 0,65 & 0,57 \\
\hline Chlor wolny & {$\left[\mathrm{mgCl}_{2} / \mathrm{dm}^{3}\right]$} & 0,85 & 0,53 & 0,40 & 0,15 \\
\hline Chlor związany & {$\left[\mathrm{mgCl}_{2} / \mathrm{dm}^{3}\right]$} & 0,52 & 0,36 & 0,25 & 0,42 \\
\hline Azot amonowy & $\begin{array}{c}{\left[\mathrm{mgN}^{3}-\right.} \\
\left.\mathrm{NH}_{4} / \mathrm{dm}^{3}\right]\end{array}$ & 0,36 & 0,47 & 0,22 & 0,26 \\
\hline Azot azotanowy & $\begin{array}{c}{\left[\mathrm{mgN}^{3}\right.} \\
\left.\mathrm{NO}_{3} / \mathrm{dm}^{3}\right]\end{array}$ & 33,00 & 44,00 & 33,00 & 43,00 \\
\hline
\end{tabular}

Szczególnie wyraźnym problemem było utrzymanie wymaganego stężenia chloru związanego, którego wartość dopuszczalna w próbkach pobranych z niecek powinna wynosić $0,2 \mathrm{mgCl}_{2} / \mathrm{dm}^{3}$ według [1] i $0,3 \mathrm{mgCl} / \mathrm{dm}^{3}$ według [3]. W próbkach pobranych z niecki basenu do nauki pływalnia stężenie chloramin wyraźne przekraczało normę, co mogło być związane np. z wysokim obciążeniem niecek osobami kąpiącymi się, niewystarczającym uzupełnianiem obiegów wodą wodociągową lub niską sprawnością przebiegu procesów uzdatniania wody $[11,12]$.

Ważnym zjawiskiem jest obniżenie stężenia chloru wolnego po procesie filtracji, które zaobserwowano na podstawie wartości dla prefiltratu i filtratu w obiegu wanny z hydromasażem, czego przyczyną może być absorpcja na antracycie. Jednocześnie wzrosło stężenie chloramin co związane jest $\mathrm{z}$ wiązaniem zanieczyszczeń organicznych na drodze przepływu wody przez złoże.

Kolejnym ważnym wskaźnikiem jest stężenie azotu amonowego w wodzie basenowej, ponieważ stosunek ilościowy jaki tworzy z chlorem wolnym ma zasadniczy wpływ na rozkład stosunku ilościowego mono-, di-i trichloraminy oraz chlorowcopochodnych azotowych związków organicznych [11-13]. Według DIN 19643 maksymalna zawartość azotu amonowego w nieckach basenowych wynosi $0,5 \mathrm{mgN}-\mathrm{NH}_{4} / \mathrm{dm}^{3}$. Oznacza to, że wszystkie z próbek pobranych $\mathrm{z}$ pierwszych trzech przedstawionych obiegów spełniały wymóg normy w tym 
zakresie [1]. Ponadto na podstawie stosunków stężeń $\mathrm{Cl}_{2} / \mathrm{N}_{-} \mathrm{NH}_{4}$ można przypuszczać, że w próbce pobranej z niecki tunelu wodnego dominowała dichloramina $\left(\mathrm{Cl}_{2} / \mathrm{N}-\mathrm{NH}_{4}=4,85\right)$, z kolei w próbce pobranej z basenu do nauki pływania na głębokości $0,3 \mathrm{~m}$ dominowała monochloramina, przy stosunku ilościowym $\mathrm{Cl}_{2} / \mathrm{N}-\mathrm{NH}_{4}=0,61$.

Maksymalne stężenie azotu azotanowego regulowane jest zarówno przez normę DIN 19643, jak i Rozporządzenie Ministra Zdrowia w sprawie jakości wody na pływalniach i wynosi $20 \mathrm{mgN}-\mathrm{NO}_{3} / \mathrm{dm}^{3}$ ponad wartość zmierzoną w wodzie uzupełniającej obieg wody $[1,3]$. Wyraźne przekroczenie stężenia azotu azotanowego miało miejsce we wszystkich próbkach wody pobranych z obiegów wanny z hydromasażem oraz tunelu wodnego. Ponadto wysoka zawartość związków azotu (V) w filtratach może przyczyniać się do zatężania chlorowcopochodnych azotowych w obiegu wody basenowej.

Tabela 5. Parametry fizykochemiczne wody w obiegu basenu tunelu wodnego

Table 5. Physicochemical parameters of water in circulation for water tunnel pool

\begin{tabular}{|c|c|c|c|c|c|}
\hline \multirow{2}{*}{ Parametr } & \multirow{2}{*}{ Jednostka } & \multicolumn{4}{|c|}{ Miejsce poboru próbki wody } \\
\cline { 3 - 6 } & & Niecka & $\begin{array}{c}\text { Zbiornik } \\
\text { przelewowy }\end{array}$ & Prefiltrat & Filtrat \\
\hline Odczyn $(\mathrm{pH})$ & {$[-]$} & 7,28 & 7,85 & 6,23 & 6,90 \\
\hline $\begin{array}{c}\text { Przewodnictwo } \\
\text { właściwe }\end{array}$ & {$[\mu \mathrm{S} / \mathrm{cm}]$} & 1533 & 1590 & 2394 & 1540 \\
\hline $\begin{array}{c}\text { Absorbancja } \\
\text { UV }\end{array}$ & {$\left[\mathrm{m}_{254}^{-1}\right]$} & 4,00 & 4,70 & 109,90 & 12,50 \\
\hline Chlor całkowity & {$\left[\mathrm{mgCl}_{2} / \mathrm{dm}^{3}\right]$} & 1,18 & 0,76 & 0,02 & 0,02 \\
\hline Chlor wolny & {$\left[\mathrm{mgCl}_{2} / \mathrm{dm}^{3}\right]$} & 0,97 & 0,32 & 0,00 & 0,01 \\
\hline Chlor związany & {$\left[\mathrm{mgCl}_{2} / \mathrm{dm}^{3}\right]$} & 0,21 & 0,44 & 0,02 & 0,01 \\
\hline Azot amonowy & {$\left[\mathrm{mgN}^{3} \mathrm{NH}_{4} / \mathrm{dm}^{3}\right]$} & 0,20 & 0,35 & 1,95 & 0,30 \\
\hline Azot azotanowy & {$\left[\mathrm{mgN}_{-} \mathrm{NO}_{3} / \mathrm{dm}^{3}\right]$} & 66,00 & 61,00 & 77,00 & 110,00 \\
\hline
\end{tabular}

Próbki wody basenowej pobrane $\mathrm{z}$ dwóch obiegów wyposażonych w filtry z ziemią okrzemkową (obiegi nr 4 i 5) charakteryzowały się zarówno wyższymi wartościami $\mathrm{pH}$, jak i przewodnictwa właściwego w stosunku do próbek pobranych z obiegów wyposażonych w filtry piaskowo-antracytowe (Tabela 6 i 7). Jednak zarówno w przypadku próbek wody pobranych z niecki rekreacyjnej, jak i pływackiej standardy jakości zostały zachowane. Nieznacznie podwyższone wartości przewodnictwa właściwego odnotowano w próbkach wody pobranych z wanny do hydromasażu, zbiornika przelewowego oraz filtratu. Wartość absorbancji w nadfiolecie w próbkach pobranych ze wspólnego obiegu basenu rekreacyjnego i wanien do hydromasażu była podwyższona w stosunku do wartości przyjmowanych dla wody po procesie uzdatniania [10]. 
Tabela 6. Parametry fizykochemiczne wody w obiegu basenu rekreacyjnego oraz wanien z hydromasażem

Table 6. Physicochemical parameters of water in circulation of recreational swimming pool and hot tubes

\begin{tabular}{|c|c|c|c|c|c|c|}
\hline \multirow{2}{*}{ Parametr } & \multirow{2}{*}{ Jednostka } & \multicolumn{5}{|c|}{ Miejsce poboru próbki wody } \\
\cline { 3 - 7 } & $\begin{array}{c}\text { Niecka } \\
\text { głebokość } \\
\mathbf{0 , 0} \mathbf{~ m}\end{array}$ & $\begin{array}{c}\text { Niecka, } \\
\text { głębokość } \\
\mathbf{0 , 3} \mathbf{~ m}\end{array}$ & $\begin{array}{c}\text { Wanna z } \\
\text { hydroma- } \\
\text { sażem }\end{array}$ & $\begin{array}{c}\text { Komora } \\
\text { filtra }\end{array}$ & Filtrat \\
\hline Odczyn $(\mathrm{pH})$ & {$[-]$} & 7,38 & 7,42 & 7,88 & 8,11 & 7,42 \\
\hline $\begin{array}{c}\text { Przewodnictwo } \\
\text { właściwe }\end{array}$ & {$[\mu \mathrm{S} / \mathrm{cm}]$} & 2245 & 2001 & 3062 & 4562 & 2805 \\
\hline $\begin{array}{c}\text { Absorbancja } \\
\text { UV }\end{array}$ & {$\left[\mathrm{m}_{254}^{-1}\right]$} & 11,50 & 10,40 & 10,8 & 11,80 & 11,40 \\
\hline Chlor całkowity & {$\left[\mathrm{mgCl}_{2} / \mathrm{dm}^{3}\right]$} & 2,05 & 2,00 & 1,73 & 2,06 & 2,07 \\
\hline Chlor wolny & {$\left[\mathrm{mgCl}_{2} / \mathrm{dm}^{3}\right]$} & 0,65 & 0,65 & 0,17 & 0,58 & 0,55 \\
\hline Chlor związany & {$\left[\mathrm{mgCl}_{2} / \mathrm{dm}^{3}\right]$} & 1,40 & 1,35 & 1,56 & 1,48 & 1,52 \\
\hline Azot amonowy & $\begin{array}{c}{\left[\mathrm{mgN}^{3}\right.} \\
\left.\mathrm{NH}_{4} / \mathrm{dm}^{3}\right]\end{array}$ & 0,26 & 0,20 & 0,28 & 1,96 & 0,31 \\
\hline Azot azotanowy & $\begin{array}{c}{\left[\mathrm{mgN}^{3}\right.} \\
\left.\mathrm{NO}_{3} / \mathrm{dm}^{3}\right]\end{array}$ & 3,92 & 4,65 & 8,52 & 12,00 & 14,00 \\
\hline
\end{tabular}

Tabela 7. Parametry fizykochemiczne wody w obiegu basenu pływackiego

Table 7. Physicochemical parameters of water in circulation of swimming pool

\begin{tabular}{|c|c|c|c|c|c|}
\hline \multirow[b]{2}{*}{ Parametr } & \multirow[b]{2}{*}{ Jednostka } & \multicolumn{4}{|c|}{ Miejsce poboru próbki wody } \\
\hline & & $\begin{array}{c}\text { Niecka, } \\
\text { głębokość } \\
\mathbf{0 , 0 ~ m ~}\end{array}$ & $\begin{array}{c}\text { Niecka, } \\
\text { głębokość } \\
\mathbf{0 , 3} \mathbf{~ m} \\
\end{array}$ & $\begin{array}{c}\text { Komora } \\
\text { filtra }\end{array}$ & Filtrat \\
\hline Odczyn $(\mathrm{pH})$ & {$[-]$} & 7,72 & 7,60 & 7,58 & 7,56 \\
\hline $\begin{array}{l}\text { Przewodnictwo } \\
\text { właściwe }\end{array}$ & {$[\mu \mathrm{S} / \mathrm{cm}]$} & 2023 & 1985 & 3762 & 1923 \\
\hline $\begin{array}{c}\text { Absorbancja } \\
\text { UV }_{254}\end{array}$ & {$\left[\mathrm{~m}^{-1}\right]$} & 3,80 & 3,60 & 4,60 & 4,20 \\
\hline Chlor całkowity & {$\left[\mathrm{mgCl}_{2} / \mathrm{dm}^{3}\right]$} & 1,44 & 1,68 & 1,67 & 1,57 \\
\hline Chlor wolny & {$\left[\mathrm{mgCl}_{2} / \mathrm{dm}^{3}\right]$} & 0,63 & 0,70 & 0,69 & 0,77 \\
\hline Chlor związany & {$\left[\mathrm{mgCl}_{2} / \mathrm{dm}^{3}\right]$} & 0,81 & 0,98 & 0,88 & 0,90 \\
\hline Azot amonowy & {$\left[\mathrm{mgN}-\mathrm{NH}_{4} / \mathrm{dm}^{3}\right]$} & 0,29 & 0,24 & 0,45 & 0,32 \\
\hline Azot azotanowy & {$\left[\mathrm{mgN}-\mathrm{NO}_{3} / \mathrm{dm}^{3}\right]$} & 4,20 & 4,08 & 4,16 & 4,74 \\
\hline
\end{tabular}

Stężenia chloru wolnego w próbkach wody pobranych z niecek rekreacyjnej oraz pływackiej przekraczały normy zalecane wartości [3]. Największe przekroczenia wartości dopuszczalnych stwierdzono w przypadku stężeń chloru związanego w niecce rekreacyjnej oraz wannie $\mathrm{z}$ hydromasażem. Stężenia te wyniosły odpowiednio $1,35 \mathrm{mgCl} 2 / \mathrm{dm}^{3}$ i $1,40 \mathrm{mgCl}_{2} / \mathrm{dm}^{3}$ oraz $1,56 \mathrm{mgCl} / \mathrm{dm}^{3}$. Mniejsze stężenia chloramin odnotowano $\mathrm{w}$ niecce pływackiej $\left(0,81 \mathrm{mgCl}_{2} / \mathrm{dm}^{3}\right.$ i $\left.0,98 \mathrm{mgCl}_{2} / \mathrm{dm}^{3}\right)$, jednak nadal znacząco przekraczające wartość określoną 
w rozporządzeniu [3]. Podobne stężenia chloru związanego występowały w pobranych próbkach filtratów (Tabela 6 i 7).

Ostatnim z badanych obiegów basenowych był obieg brodzika dla dzieci (obieg nr 6) wyposażony w filtr ze złożem szklanym (AFM $\left.{ }^{\circledR}\right)$, (Tabela 8). Na podstawie analizy próbki wody z niecki oraz filtratu, stwierdzono że wartości $\mathrm{pH}$, przewodnictwa właściwego oraz absorbancji w nadfiolecie spełniają wymagania jakości w tym zakresie $[2,3,10]$. Stężenie chloru wolnego w obu badanych próbkach było zbliżone do wartości maksymalnej określonej w DIN 19643 czyli $0,6 \mathrm{mgCl}_{2} / \mathrm{dm}^{3}$. Należy zwrócić uwagę, że według rozporządzeniu Ministra Zdrowia $w$ nieckach basenowych udostępnionych do nauki pływania dla niemowląt i małych dzieci do lat 3, stężenie chloru wolnego powinno mieścić się w granicach $0,3 \quad \mathrm{mgCl}_{2} / \mathrm{dm}^{3} \div 0,4 \mathrm{mgCl}_{2} / \mathrm{dm}^{3}$. Natomiast zawartość chloramin przekroczyła ponad dwukrotnie wymaganą w DIN 19643 i rozporządzeniu Ministra Zdrowia wartość maksymalną. Zarówno stężenie azotu amonowego, jak i azotanowego w badanych próbkach odpowiadało wymaganiom określonym dla pływalni [1-3]. Ponadto na podstawie stosunku ilościowego chloru wolnego do azotu amonowego w próbce wody z niecki oraz filtracie $\left(\mathrm{Cl}_{2} / \mathrm{N}_{-}-\mathrm{NH}_{4}=2,32\right.$ oraz $2,09)$ stwierdzono, że w badanych próbkach przeważała monochloramina [11].

Tabela 8. Parametry fizykochemiczne wody w obiegu brodzik dla dzieci

Table 8. Physicochemical parameters of water in circulation of paddling pool for children

\begin{tabular}{|c|c|c|c|}
\hline \multirow{2}{*}{ Parametr } & \multirow{2}{*}{ Jednostka } & \multicolumn{2}{|c|}{ Miejsce poboru próbek wody } \\
\cline { 3 - 4 } & {$[-]$} & Niecka & Filtrat \\
\hline Odczyn $(\mathrm{pH})$ & {$[\mu \mathrm{S} / \mathrm{cm}]$} & 7,33 & 7,62 \\
\hline $\begin{array}{c}\text { Przewodnictwo wła- } \\
\text { ściwe }\end{array}$ & {$\left[\mathrm{m}^{-1}\right]$} & 1806 & 1852 \\
\hline Absorbancja UV $\mathrm{U}_{254}$ & {$\left[\mathrm{mgCl}_{2} / \mathrm{dm}^{3}\right]$} & 2,10 & 1,70 \\
\hline Chlor całkowity & {$\left[\mathrm{mgCl}_{2} / \mathrm{dm}^{3}\right]$} & 1,09 & 1,24 \\
\hline Chlor wolny & {$\left[\mathrm{mgCl}_{2} / \mathrm{dm}^{3}\right]$} & 0,58 & 0,67 \\
\hline Chlor związany & {$\left[\mathrm{mgN}_{-} \mathrm{NH}_{4} / \mathrm{dm}^{3}\right]$} & 0,51 & 0,57 \\
\hline Azot amonowy & {$\left[\mathrm{mgN}_{-} \mathrm{NO}_{3} / \mathrm{dm}^{3}\right]$} & 0,25 & 0,32 \\
\hline Azot azotanowy & 2,69 & 2,53 \\
\hline
\end{tabular}

\subsection{Ocena toksykologiczna}

Ze względu na wysokie stężenia chloramin przeprowadzona ocena toksykologiczna obejmowała dwa obiegi: $\mathrm{z}$ filtrem z ziemią okrzemkową oraz z filtrem ze złożem szklanym. Na rys. 1 przedstawiono wyniki testu Microtox ${ }^{\circledR}$ dla wspólnego obiegu basenu rekreacyjnego i wanien z hydromasażem po czasie ekspozycji 5 oraz 15 minut. Wszystkie badane próbki wykazywały wysoką toksyczność w stosunku do organizmów testowych, inhibicja bioluminescencji bakterii w teście Microtox ${ }^{\circledR}$ po czasie ekspozycji 15 minut przekroczyła $99 \%$. 


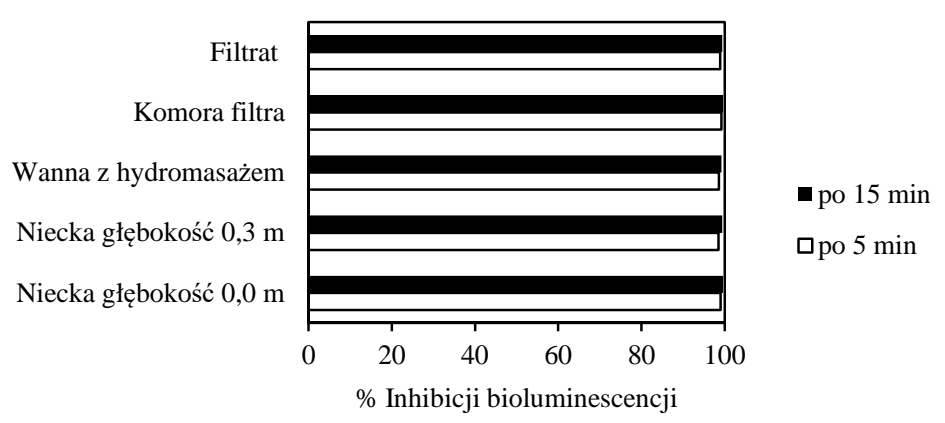

Rys. 1. Inhibicja bioluminescencji $\mathrm{w}$ teście Microtox ${ }^{(B)} \mathrm{w}$ obecności próbek z wspólnego obiegu basenu rekreacyjnego i wanny z hydromasażem

Fig. 1. Inhibition of bioluminescence in Microtox ${ }^{\circledR}$ assay in the presence of water samples from common swimming pool water circulation recreational pool and hot tubes

Śmiertelność skorupiaków Daphnia magna (Rys. 2) po 48 godzinach od rozpoczęcia testu wyniosła $100 \%$, aż w trzech z czterech próbek. Natomiast $\mathrm{w}$ próbce pobranej z komory filtra z ziemią okrzemkową odnotowano unieruchomienie u $90 \%$ organizmów testowych.

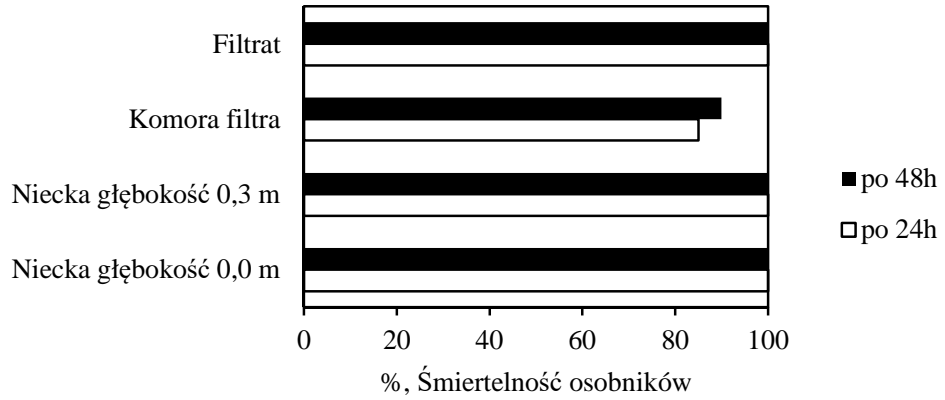

Rys. 2. Śmiertelność osobników Daphnia magna w obecności próbek wody pobranych z obiegu basenu rekreacyjnego i wanny z hydromasażem

Fig. 2. Lethality of individuals Daphnia magna in the presence of water samples taken from common circulation recreational pool and hot tubes

Na podstawie wyników biotestów stwierdzono, że zarówno bakterie Aliivibirio ficheri jak i skorupiaki Daphnia magna są szczególnie wrażliwe na występujące w wodach basenowych związki chemiczne. Niższą śmiertelność osobników Daphnia magna w próbce pobranej z komory filtra może być związana z niższym stężeniem chloru wolnego, które w tym przypadku wynosiło $0,17 \mathrm{mgCl}_{2} / \mathrm{dm}^{3}$. W pozostałych próbkach zawartość stężenie chloru wolnego wynosiło $0,55 \mathrm{mgCl} / \mathrm{dm}^{3}$ i $0,65 \mathrm{mgCl}_{2} / \mathrm{dm}^{3}$, co mogło przyczynić się do wyższej śmiertelności w efekcie powstawania ubocznych produktów dezynfekcji. 
Na rys 3 i rys. 4 przedstawiono wyniki biotestów dla próbek pobranych $\mathrm{z}$ obiegu basenu pływackiego.

Inhibicja bioluminescencji wszystkich próbek wody po czasie ekspozycji 15 minut przekroczyła 99\%. Również w teście ze skorupiakami Daphnia magna uzyskano wysokie wartości toksyczność. Próbki filtratu, wody z komory filtra oraz wody z niecki na głębokości $0,3 \mathrm{~m}$ spowodowały unieruchomienia $100 \%$ osobników po 48 godzinach ekspozycji. Próbka wody pobrana z niecki na poziomie lustra wody $(0,0 \mathrm{~m})$ przyczyniła się do $95 \%$ śmiertelności organizmów.

Powyższych zależności między wynikami testu śmiertelności Daphnia magna a stężeniem chloru wolnego nie zaobserwowano dla próbek pobranych z obiegu brodzika dla dzieci (Rys. 5). Śmiertelność organizmów testowych zarówno $\mathrm{w}$ próbce pobranej $\mathrm{z}$ niecki basenowej, jak i filtratu wyniosła $100 \%$. Również w bioteście Microtox ${ }^{\circledR}$ niższa wartość inhibicji bioluminescencji nie znajduje odzwierciedlenia w mniejszym stężeniu chloru wolnego (Rys. 6).

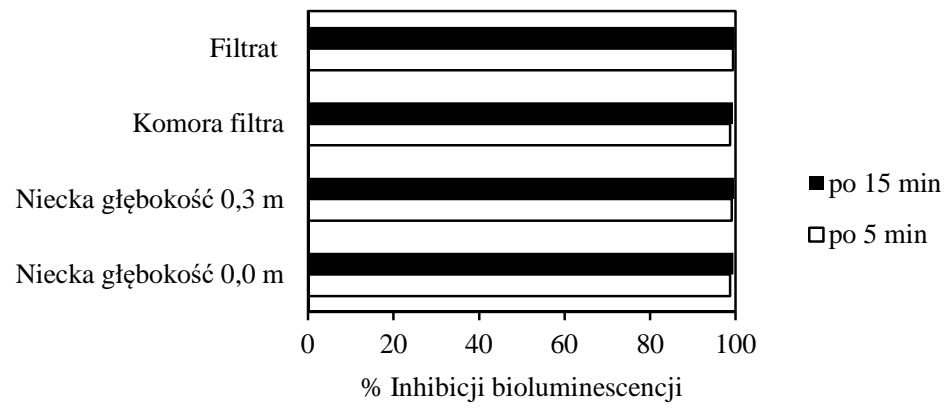

Rys. 3. Inhibicja bioluminescencji w teście Microtox ${ }^{(\circledR)}$ w obecności próbek z obiegu basenu pływackiego

Fig. 3. Inhibition of bioluminescence in Microtox ${ }^{\circledR}$ assay in the presence of water samples from swimming pool water circulation

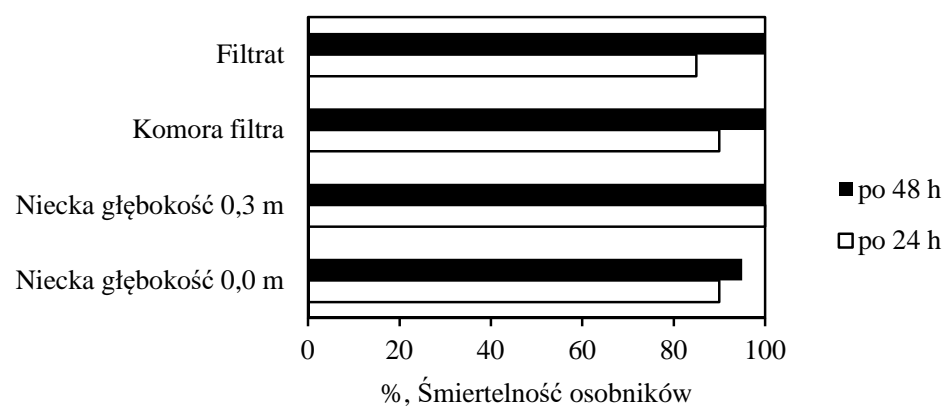

Rys. 4. Śmiertelność osobników Daphnia magna w obecności próbek z obiegu basenu pływackiego

Fig. 4. Lethality of individuals Daphnia magna in the presence of water samples taken from swimming pool water circulation 


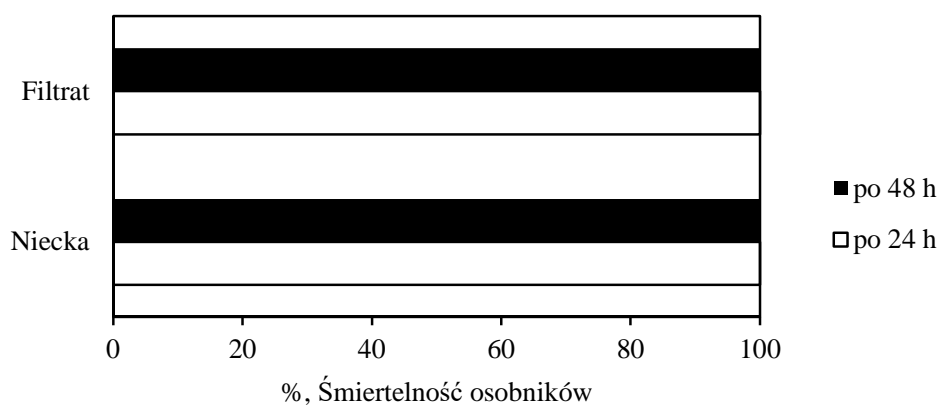

Rys. 5. Śmiertelność osobników Daphnia magna w obecności próbek z brodzika dla dzieci

Fig. 5. Lethality of individuals Daphnia magna in the presence of water samples taken from circulation of paddling pool for children

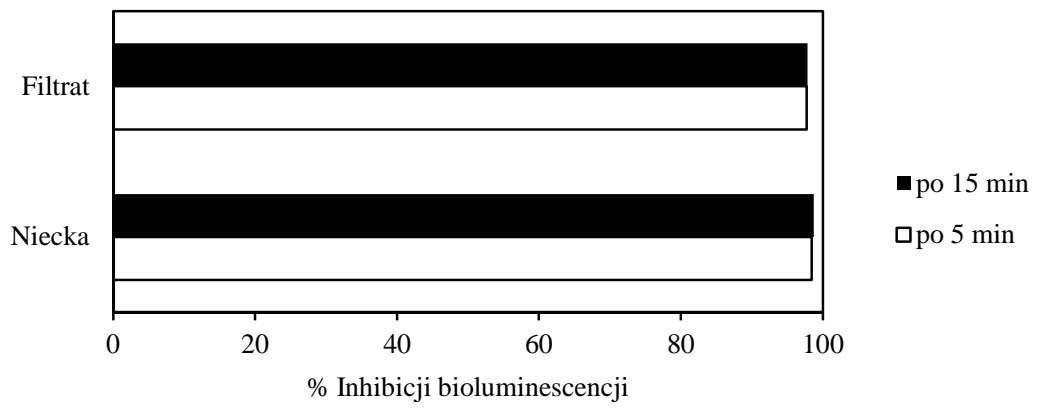

Rys. 6. Inhibicja bioluminescencji w teście Microtox ${ }^{\circledR}$ w obecności próbek z brodzika dla dzieci

Fig. 6. Inhibition of bioluminescence in Microtox ${ }^{\circledR}$ assay in the presence of water samples taken from circulation of paddling pool for children

Natomiast mniejsze stężenia chloru, w stosunku do próbek pobranych z obiegów basenu pływackiego i rekreacyjnego, wpłynęły na obniżenie wartości inhibicji bioluminescencji poniżej 99\%, która to wartość dominowała we wcześniej opisanych obiegach.

Na podstawie przeprowadzonej oceny toksykologicznej stwierdzono, że substancje organiczne i nieorganiczne obecne w badanych próbkach były wysoko toksyczne dla wykorzystanych organizmów wskaźnikowych. 


\section{Podsumowanie}

Jedynym obiegiem, który spełniał aktualne wytyczne co do jakości wody basenowej był obieg basenu do nauki pływania, w którym proces filtracji obejmował filtrację ciśnieniową w złożu wielowarstwowym. Najpoważniejszym problemem w pozostałych obiegach wody basenowej były bardzo wysokie stężenia chloramin, znacznie przekraczające wartości dopuszczalne Najwyższą zawartość chloru związanego odnotowano we wspólnym obiegu basenu rekreacyjnego $\mathrm{i}$ wanien $\mathrm{z}$ hydromasażem oraz $\mathrm{w}$ obiegu basenu pływackiego. $\mathrm{W}$ obu przypadkach systemy filtracji wyposażone są w podciśnieniowe filtry $\mathrm{z}$ ziemią okrzemkową. W żadnym z obiegów nie występowało przekroczenie wartości dopuszczalnych dla azotu amonowego, określonych w rozporządzeniu czy normie DIN 19643 [1, 3]. Natomiast znaczące przekroczenie stężenia azotu azotanowego występowało we wszystkich próbkach pobranych z obiegów z filtrami wielowarstwowymi, dla wanny $\mathrm{z}$ hydromasażem oraz tunelu wodnego.

Większość parametrów fizykochemicznych dla próbek wody pobranych z obiegu brodzika dla dzieci z filtrem ze szklanym złożem spełniało wymagania. Natomiast stężenie chloru związanego $\mathrm{w}$ próbkach pobranych $\mathrm{z}$ tego obiegu przekraczało dwukrotnie wartość określoną rozporządzeniem [3].

Przedstawione wyniki badań pokazują, że zachowanie odpowiedniej jakości wody basenowej, zgodnej z rygorystycznymi wymaganiami w tym zakresie stanowi duże wyzwanie dla wielu zarządców obiektów basenowych. Szczególnie ważne jest zapobieganie tworzeniu się dużych (ponad $0,3 \mathrm{mgCl}_{2} / \mathrm{dm}^{3}$ ) stężeń chloramin, które odpowiedzialne są za tzw. zespół podrażnienia u pływaków, suchość skóry, podrażnienia śluzówki nosa, gardła i oczu, nadają wodzie basenowej i powietrzu w hali basenowej charakterystyczny nieprzyjemny zapach i posiadają właściwości mutagenne.

Przeprowadzona ocena toksykologiczna wskazuje również na potencjalnie wysoką szkodliwość badanej wody basenowej dla organizmów żywych, co spowodowane jest obecnością związków chemicznych występujących w próbkach.

\section{Literatura}

[1] DIN 19643 Aufbereitung von Schwimm und Badebeckenwasser, Düsseldorf 1997.

[2] Rozporządzenie Ministra Zdrowia z dnia 13 listopada 2015 roku w sprawie jakości wody przeznaczonej do spożycia. Dz. U. 2015. poz. 1989.

[3] Rozporządzenie Ministra Zdrowia z dnia 9 listopada 2015 roku w sprawie wymagań, jakim powinna odpowiadać woda na pływalniach. Dz. U. 2015. poz. 2016.

[4] Piechurski F.: Metody i systemy filtracji wody basenowej cz. 1., Pływalnie i Baseny, nr 5, 2010, s. 88-94.

[6] Łaskawiec E., Dudziak M., Wyczarska-Kokot J.: Ocena toksykologiczna jakości wody krytego obiektu basenowego w: Współczesne problemy ochrony środowiska III, praca zbiorowa pod red. Pikonia K., Bogackiej M., Archiwum Gospodarki Odpadami i Ochrony Środowiska, 2015, s. 193-202. 
[7] Potter B., Wimsatt J.: Determination of total organic carbon and specific UV absorbance at $254 \mathrm{~nm}$ in source water and drinking water". EPA Document, 2009, Method 415.3.

[8] Daphnia sp., Acute Immobilisation Test and Reproduction Test, OECD Guideline for testing of chemicals. 1984, 202: pp. 1-16.

[9] Persoone, G., Marsalek, B., Blinova, I., Torokne, A., Zarina, D., Manusadžianas, L., Nalecz-Jawecki, G., Tofan, L., Stepanova, N., Tothova, L., Kolar, B.: A practical and user-friendly toxicity classification system with microbiotests for natural waters and wastewaters, Environmental Toxicology 18 (6), 2003, pp. 395 - 402.

[10] Nowacka A. Włodarczyk-Makuła M.: Zmiany absorbancji w nadfiolecie (UV254) w wodzie w procesach uzdatniania, LAB Laboratoria Aparatura Badania, R. 17 nr.1, 2012, s. 28-31.

[11] Świderska-Bróż M., Kowal A. L., Oczyszczanie wody. Podstawy teoretyczne i technologiczne, procesy i urządzenia, Wydawnictwo Naukowe PWN, Warszawa 2005. [12] Wyczarska-Kokot J., Porównanie stężeń chloramin w wodzie basenowej w zależności od funkcji basenu, Proccedings of ECOpole, vol. 9 no. 1, 2015, s. 357-363.

[13] Wyczarska-Kokot J.: Analiza stężeń chloramin w wodzie basenowej. Praca zbiorowa pod red. Dymaczewski Z., Jeż-Walkowiak J., Nowak M.: Zaopatrzenie w wodę, jakość i ochrona wód, Poznań, Toruń 2014, s. 951-963.

\title{
THE SWIMMING POOL WATER QUALITY ANALYSIS IN CYCLES OF VARIOUS FILTRATION SYSTEMS
}

\begin{abstract}
S u m m a r y
The paper presents the results of physicochemical analyses and toxicological evaluation of swimming-pool water circuits. The primary difference in applied circuit water technologies is the method of its filtration. The following types of water filters were selected for qualitative assessment: pressure filters with anthracite and sand medium, and Activated Filter Material $\mathrm{AFM}^{\circledR}$, as well as vacuum filter using diatomaceous earth (DE). In addition, the research objects were used in pools of various applications. Toxicological evaluation of collected samples was carried out based on luminescence inhibition test $\left(\right.$ Microtox $^{\circledR}$ ) and Daphnia magna survival and growth test. Physicochemical analysis of samples of pool water indicates high diversity of its quality. In the vast majority of sampling points the concentration of free and combined chlorine was far above the limit values specified in DIN 19643 and regulation of the Minister of Health. The results of the conducted biotests indicate high toxicity of swimming pool water in relation to test organisms. Support of the physicochemical analysis with toxicological tools allows for a more complete description of pool water quality. The presented research results show that maintaining acceptable quality of swimming pool water, in accordance with stringent requirements in this regard, constitutes a major challenge for many managers of confined water objects. A particularly distinct problem is exceeded norms of chloramines that, in addition to its irritant action on the respiratory tract and mucous membranes of humans, also possess mutagenic properties.
\end{abstract}

Keywords: physico-chemical indicators, chloramine, toxicological assessment, toxicological classification

Przestano do redakcji: 20.04.2016 r.

Przyjęto do druku: 30.05.2016 $r$.

DOI: $10.7862 / \mathrm{rb} .2016 .117$ 